\title{
NEEM OIL ANTIFEEDANT AND INSECTICIDAL EFFECTS ON Oebalus poecilus (HEMIPTERA: PENTATOMIDAE) MALES AND FEMALES ${ }^{1}$
}

\author{
Patricia Valle Pinheiro ${ }^{2}$, Eliane Dias Quintela²
}

\section{RESUMO \\ EFEITO INSETICIDA E DETERRENTE \\ DO ÓLEO DE NIM EM MACHOS E FÊMEAS DE Oebalus poecilus (HEMIPTERA: PENTATOMIDAE)}

Avaliou-se o efeito das formulações comerciais de óleo de nim (Azadirachta indica) Dalneem e Nim-I-Go sobre a alimentação e sobrevivência de $O$. poecilus, em arroz irrigado. $\mathrm{O}$ efeito sobre a alimentação foi avaliado nas concentrações de $1 \%$ e $2 \%(\mathrm{v} / \mathrm{v})$ das formulações. O efeito inseticida foi avaliado nas concentrações de $0,5 \% ; 1 \% ; 2 \%$; e $4 \%$ (v/v) de Dalneem, por ingestão. Os experimentos foram realizados com quatro repetições por tratamento, contendo uma panícula e insetos adultos separados por sexo (dois insetos por parcela, para o efeito sobre a alimentação, e cinco, para o efeito inseticida). Os dois produtos foram igualmente eficientes na redução dos danos causados pelos insetos. Os insetos alimentaram-se menos das panículas tratadas, causando menor número de bainhas de estilete/grão e menos grãos danificados do que no controle. A massa das espiguetas foi maior nas panículas tratadas. Na testemunha, as fêmeas causaram danos significativamente maiores que os machos, para número de bainhas de estilete e Índice de Deterrência da Alimentação. Apenas na concentração de $4 \%$ (v/v), o Dalneem causou mortalidade de adultos significativamente superior à da testemunha. Conclui-se que os óleos de nim testados, em concentrações $\geq 1 \%$ (v/v), podem ser utilizados para reduzir os danos quantitativos e qualitativos causados por $O$. poecilus, em arroz.

PALAVRAS-CHAVE: Percevejo da panícula; Azadirachta indica; danos qualitativos; Oryza sativa; extrato botânico.

\section{INTRODUCTION}

Oebalus poecilus (Dallas) (Hemiptera: Pentatomidae) is considered the most important rice pest in South and Central America (Sutherland \& Baharally 2003), feeding on its panicles, mainly in irrigated rice areas. In Brazil, it can be found in all rice producing regions (Ferreira 1999). The damage caused by this bug is characterized by the presence

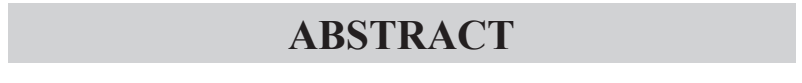

The antifeedant and insecticidal effects of two commercial neem (Azadirachta indica) oil formulations (Dalneem and Nim-I-Go) to Oebalus poecilus were evaluated on irrigated rice. To evaluate the antifeedant effect, both formulations were tested at $1 \%$ and $2 \%(\mathrm{v} / \mathrm{v})$ concentration levels. The insecticidal effect was evaluated at $0.5 \%, 1 \%$, $2 \%$, and $4 \%(\mathrm{v} / \mathrm{v})$ concentrations of Dalneem, by ingestion. Both experiments were conducted with four replications by treatment, containing one panicle and adult insects segregated by gender (two insects per plot for the antifeedant effect and five for the insecticidal effect). Both products were efficient, reducing the damage caused by insects. Insects fed less on the panicles treated with neem oil, causing lower number of feeding sheaths per panicle and lower percentage of damaged grains than the control. Spikelets weight was higher in panicles treated with neem oils. Females caused significantly higher damage than males in controls, for numbers of feeding sheaths and for the feeding deterrence index. Only at the 4\% (v/v) concentration level, Dalneem caused adult mortality higher than in the control. Results showed that neem oil formulations, at $\geq 1 \%(\mathrm{v} / \mathrm{v})$ concentration, can be used to reduce the quantitative and qualitative damages caused by O. poecilus in lowland rice.

KEY-WORDS: Small rice stink bug; Azadirachta indica; qualitative damages; Oryza sativa; botanical extract.

of scars on rice grains, known as feeding sheaths, located where insects introduced their stylets. In those scars, grains become weak and can cleave at milling, causing damages to grain quality. Qualitative damage depends on the population density and on the insect development stage. As this insect is a vector of fungi (Kennard 1966), the intensity of scars in grains can increase, according to the $O$. poecillus feeding activity (Silva et al. 2002). 
Quantitative damage, like weight reduction, for example, can occur when there is high infestation at the milky stage of grains (Ferreira 1999). Differences in the damage caused by males and females were observed in another species of the O. pugnax genus (Bowling 1979, Rashid et al. 2005). Although many authors refer to differences in feeding intensity between males and females of some heteropteran species (Buntin et al. 1996, Lacerda et al. 2004), little is known about the behavior of $O$. poecilus males and females or how this could affect the management of this insect pest. Researches have been carried out to develop technologies for rice production with low use of agrochemicals, because this crop is a staple food for a large part of the world population (Macilwain 1999, Huang et al. 2002).

The neem tree (Azadirachta indica A. Juss) is one of the most studied plants with toxicity properties against insect pests and it is considered safe for human health and environment. Neem products activity persists on plants about four to seven days after its application (Ahmad et al. 1995, Quintela \& Pinheiro 2009), which means it presents fast degradation and, consequently, a low intoxication risk to mammalians and birds (Martinez 2002).

Due to its several ways of action and the azadiracthin molecule complexity, insects are hardly selected by resistance to neem compounds (Martinez 2002). These insecticides can be produced on the farm at a low cost and its residues do not remain on foods (Roel 2001). Many studies refer to the efficiency of neem against some rice insect pests, reducing damages on plants, as insecticide, antifeedant, oviposition-deterrent, and repellent (Rajappan et al. 2000, Dash et al. 2001, Sankari \& Narayanasamy 2007). Additionally, some previous studies have shown that neem oil can cause antifeedant effects on heteropteran pests, as it was observed for Nezara viridula (Hemiptera: Pentatomidae) (Abudulai et al. 2003, Mitchel et al. 2004, Singha et al. 2007). However, the only report of the neem oil formulations effect to control $O$. poecilus was pointed out by Sutherland et al. (2002). Those authors registered that crude neem kernel extracts and neem formulations commercialized in Guyana, at the recommended rates, had antifeedant effects on $O$. poecilus and that commercialized products were responsible for higher mortality levels of adults than the extracts. Nevertheless, in Brazil, most of the neem oils commercialized were not evaluated yet about their efficiency to reduce the populations of many important pests, like $O$. poecilus, for example, and so, there is not a recommended rate for these products to be used in the management of crop pests.

The objective of the present study was to determine the efficiency of two neem oils commercialized in Brazil as antifeedant against $O$. poecilus males and females on rice, under screenhouse conditions.

\section{MATERIAL AND METHODS}

Experiments were conducted at Embrapa Arroz e Feijão $\left(16^{\circ} 28^{\prime} 00^{\prime \prime} \mathrm{S}, 49^{\circ} 17^{\prime} 00^{\prime \prime} \mathrm{W}\right.$, altitude $823 \mathrm{~m}$ ), in Santo Antônio de Goiás, GO, Brazil, in 2002. Insects were obtained from the insect rearing maintained on rice plants, in a screenhouse. The commercial emulsions of neem oil Dalneem (Dalquim Ltda., Itajaí, Brazil) and Nim-I-Go (Agroecológica, Campinas, Brazil) were used in bioassays.

Three rice plants, cultivar BRS Formoso, were transplanted to each pot to keep plants green during the first bioassay. From these plants, one panicle was used per plot, after being isolated at the flowering stage, in cages manufactured using two-liters plastic bottles. To manufacture the cages, the bottles bottons were removed and covered by a nylon screen. At the grain filling stage, cages were removed and panicles in the same pot were sprayed with Dalneem or Nim-I-Go, diluted in distilled water at $1 \%$ or $2 \%(\mathrm{v} / \mathrm{v})$ concentration levels, with $500 \mathrm{~mL}$ of suspension, using a micro sprayer (Paasche airbrusch type $\mathrm{H}$-set). Concentration levels tested in bioassays were determined by a previous screening test. The control plants were sprayed only with distilled water. Two hours after sprayed, panicles were already dry and then each panicle was covered with the same cage, where two $O$. poecilus adults (3-5 days old) were introduced, representing one replicate.

Treatments were arranged in a completely randomized design, with four replications, and each replication consisted of a different rice plot, in which only insects of the same gender (males or females) were introduced. Each treatment comprised of a combination of the three factors studied: neem products (Dalneem or Nim-I-Go), neem products concentration levels ( $1 \%$ or $2 \% \mathrm{v} / \mathrm{v}$ concentrations), and insect gender (male or female). There were two controls: one with insects (segregated by gender) and another without insects. 
Dead insects were replaced daily, during one week. After that, insects were removed and panicles were maintained isolated in the cages, until harvesting. Counts of number of feeding sheaths per spikelet and damaged grains were made after immersing a 50-grains size sample in a $70 \%$ ethanol and $0.5 \%$ sodium hydroxide solution, during 24 hours, to visualize the grain scars. After that, samples were washed and evaluated under a slim layer of water in a white bottom tray. The number of spikelets per panicle were counted and the weight of 100 spikelets were evaluated using an analytical balance.

The second bioassay was carried out to evaluate the insecticidal activity of neem oil against O. poecilus, by ingestion. For that, three rice panicles were treated with $500 \mathrm{~mL}$ of Dalneem, at the $0.5 \%$, $1 \%, 2 \%$, and $4 \%(\mathrm{v} / \mathrm{v})$ concentration levels, and placed into a Becker containing $500 \mathrm{~mL}$ of water, covered by a plastic cage $(10 \mathrm{~cm} \times 30 \mathrm{~cm})$, using ten replicates per treatment. The control plants were sprayed only with distilled water. In every cage, five adult insects were introduced. Every two days, fresh panicles treated with neem oil, at the same concentration levels, replaced the old ones. Counts of dead insects were observed and registered daily, until the tenth day after spraying.

For the first experiment, data were submitted to a $2 \times 2 \times 2$ factorial variance analysis, plus two controls. Factors were neem oil commercial products (Dalneem and Nim-I-Go), their concentration levels ( $1 \%$ and $2 \%$ ), and insect gender (male or female). Spikelets weight and number of feeding sheaths were transformed using $\sqrt{x+1}$. Percentages of damaged grains were transformed using arccosine $\sqrt{x / 100}$. For all variables, least-squares means were separated by using the PDIFF option of SAS, when significant $(p<0.05)$ F values were observed (GLM procedure of SAS) (SAS Institute 2002).
Feeding deterrence index (FDI) was calculated based on the number of feeding sheaths per spikelet, using the expression $[(\mathrm{A}-\mathrm{B}) /(\mathrm{A}+\mathrm{B})] \mathrm{x} 100$, where $A=$ number of feeding sheaths on panicles treated with neem oils and $\mathrm{B}=$ number of feeding sheaths on positive controls (adapted from Fenemore 1980). Values for index ranged from +100 for total stimulation, through 0 for no effect, to -100 for total deterrence. Feeding deterrence index means were compared to positive control using a t test $(p<0.01)$. For the second experiment, percentages of insect mortality were transformed using arccosine $\sqrt{x / 100}$ and means were separated by using the PDIFF option of LSMEANS statement of SAS (SAS Institute 2002).

\section{RESULTS AND DISCUSSION}

Highly significant effects of neem oil and concentration factors were observed for the variable feeding sheaths of $O$. poecilus per spikelet $(\mathrm{p}<0.0001)$ (Table 1). Insect gender had significant effect on spikelets weight $(\mathrm{p}<0.0256)$ and percentage of damaged grains $(p<0.001)$. No significant interaction was observed between factors.

Neem oils significantly reduced the damage in rice grains, caused by $O$. poecilus males and females, in comparison with the positive control (Table 2). Quantitative damage was reduced in treated panicles, indicated by the higher spikelets weight from treated plants, when compared with untreated ones (positive control). In the treatments where rice plants were sprayed with neem oils and submitted to insect females infestation, the spikelets weight was three-fold higher than in the positive control with females. For males, the application of neem products resulted in twice the spikelets weight, in comparison

Table 1. Summary of factorial analysis for spikelets weight, damaged grains, and feeding sheaths per spikelet caused by Oebalus poecilus adult males and females, subsequent to rice panicles treatment with neem oils, at different concentration levels (Santo Antônio de Goiás, GO, 2002).

\begin{tabular}{lccc}
\hline \multirow{2}{*}{ Source } & \multicolumn{3}{c}{ Probability $>$ F } \\
\cline { 2 - 4 } & Spikelets weight & Damaged grains & Feeding sheaths/ spikelet \\
\hline Neem oil & 0.1217 & 0.4037 & $<0.0001$ \\
Concentration level & 0.3815 & 0.0619 & $<0.0001$ \\
Insect gender & 0.0256 & 0.0001 & 0.1268 \\
Neem oil x Concentration level & 0.3879 & 0.4450 & 0.5079 \\
Neem oil x Insect gender & 0.1963 & 0.3001 & 0.8900 \\
Concentration level x Insect gender & 0.6873 & 0.7885 & 0.0565 \\
Neem oil x Concentration level x Insect gender & 0.6484 & 0.5658 & 0.6048 \\
\hline CV $(\%)$ & 20.05 & 29.32 & 16.67 \\
\hline
\end{tabular}


Table 2. Weight of 100 spikelets, percentage of damaged grains, and number of feeding sheaths per spikelet caused by Oebalus poecilus adult males and females, after treatment of rice panicles with neem oils, at different concentrations and feeding deterrence index (FDI) of neem oil formulations on rice panicles, for Oebalus poecilus males and females (Santo Antônio de Goiás, GO, 2002).

\begin{tabular}{|c|c|c|c|c|c|c|c|c|c|}
\hline \multirow[t]{2}{*}{ Treatment } & \multirow[t]{2}{*}{$\mathrm{C}(\%)$} & \multicolumn{2}{|c|}{$\begin{array}{l}\text { Weight of } 100 \\
\text { spikelets }^{1}(\mathrm{~g})\end{array}$} & \multicolumn{2}{|c|}{$\begin{array}{l}\text { Damaged grains }^{1} \\
(\%)\end{array}$} & \multicolumn{2}{|c|}{$\begin{array}{c}\text { Feeding sheaths/ } \\
\text { spikelet }^{1}\end{array}$} & \multicolumn{2}{|c|}{$\begin{array}{l}\text { Feeding deterrence index } \\
(\mathrm{FDI})^{2}\end{array}$} \\
\hline & & Males & Females & Males & Females & Males & Females & Males & Females \\
\hline \multirow[t]{2}{*}{ Dalneem } & 1.0 & $3.56 \mathrm{a}$ & $3.03 \mathrm{a}$ & $14.9 \mathrm{~b}$ & $20.4 \mathrm{~b}$ & $1.38 \mathrm{ab}$ & $1.54 \mathrm{~b}$ & $-26.8^{n s}$ & $-33.8 \mathrm{~ns}$ \\
\hline & 2.0 & $3.94 \mathrm{a}$ & $3.38 \mathrm{a}$ & $10.2 \mathrm{~b}$ & $9.3 \mathrm{~b}$ & $1.27 \mathrm{a}$ & $1.04 \mathrm{a}$ & $-30.8^{n s}$ & $-49.6 * *$ \\
\hline \multirow[t]{2}{*}{ Nim-I-Go } & 1.0 & $3.23 \mathrm{a}$ & $3.06 \mathrm{a}$ & $9.1 \mathrm{~b}$ & $18.3 \mathrm{~b}$ & $1.96 \mathrm{c}$ & $2.02 \mathrm{c}$ & $-12.7^{\mathrm{ns}}$ & $-20.7^{n s}$ \\
\hline & 2.0 & $3.05 \mathrm{a}$ & $3.24 \mathrm{a}$ & $5.6 \mathrm{a}$ & $14.6 \mathrm{~b}$ & $1.60 \mathrm{bc}$ & $1.45 \mathrm{~b}$ & $-20.4^{\mathrm{ns}}$ & $-35.8 *$ \\
\hline Control + (with insects) & 0 & $1.82 \mathrm{~b}$ & $0.95 \mathrm{~b}$ & $22.5 \mathrm{~b}$ & $58.0 \mathrm{c}$ & $2.29 \mathrm{~d}$ & $2.93 \mathrm{~d}$ & 0 & 0 \\
\hline Control - (no insects) & 0 & \multicolumn{2}{|c|}{$4.26 \mathrm{a}$} & \multicolumn{2}{|c|}{$1.5 \mathrm{a}$} & \multicolumn{2}{|c|}{0} & \multicolumn{2}{|c|}{ - } \\
\hline
\end{tabular}

${ }^{1}$ Means followed by the same letter in the columns are not significantly different ( $\mathrm{t}$ multiple range test; $\left.\mathrm{p}<0.05\right) .{ }^{2}$ The feeding deterrence index (FDI) was calculated based on number of feeding sheaths per spikelet, using the expression $[(A-B) /(A+B)] x 100$, where $A=$ number of feeding sheaths on panicles treated with neem oils and $\mathrm{B}=$ number of feeding sheaths on positive controls (adapted from Fenemore 1980). Index values ranged from +100 for total stimulation, through 0 for no effect, to -100 for total deterrence. ${ }^{n s}$ not significant; * significant $(\mathrm{p}<0.05) ; * *$ significant $(\mathrm{p}<0.01)$, in comparison with the control $(\mathrm{FDI}=0 \%)$, using a t test.

with positive controls with males. There was no significant difference in spikelets weight between treated panicles and those which were held in the absence of insects (Table 2).

Both neem products significantly reduced the percentage of grains that were damaged by females, when compared with positive control (Table 2), but no significant difference between formulations and concentrations was observed. Nevertheless, for males, only Nim-I-Go at the $2 \%$ concentration level showed a percentage of damaged grains significantly equal to the absence of insects. Sutherland et al. (2002) also observed that panicles treated with different formulations of azadirachtin, the main compound of neem oil, showed significant reduction on percentage of grains damaged by $O$. poecilus. However, those authors did not report which insect gender was tested in bioassays. In the present work, the number of feeding sheaths per spikelet were significantly lower in plants treated with neem oil, indicating that both males and females had fed less on treated panicles and, consequently, qualitative damage was also reduced (Table 2).

The $2 \%$ concentration level, for both neem products, was the most efficient to reduce the number of feeding sheaths for females (Table 2). Nim-I-Go at $1 \%$ and $2 \%$ concentration levels presented the highest number of feeding sheaths per spikelet, for both males and females, when compared with Dalneem. The feeding deterrence index (FDI) for males was not significant, when compared with the control (Table 2). For females, the $2 \%$ concentration level of both products was responsible for a significant FDI, inhibiting female's activity.
Differences between the damage caused by males and females were observed only for damaged grains in panicles treated with Nim-I-Go and for the feeding deterrence index (FDI), for both products, always higher for females (Table 3 ). In the controls, females were also responsible for higher damages than males, for all variables analyzed. Females caused over twice the damaged grains than males (58\% versus $22.5 \%$ ), in the positive control (Table 3). Similar results were reported by Rashid et al. (2005), for O. pugnax, who registered that a higher percentage of females fed on different host plants than males, over an initial 24 hours period. The number of feeding sheaths left on treated panicles was similar for females and males, although, in controls, females left a higher number of feeding sheaths on panicles than males (Table 3). Similarly, Bowling (1979) observed that females of $O$. pugnax produced twice the number of feeding sheaths than males, on rice. The spikelets weight showed no difference between males and females, for the treated panicles in the present work.

The FDI was higher for females, when compared with males, for both neem products (Table 3). This result was already expected, since females left significantly more feeding sheaths on panicles than males. As the damage caused by females on grains was higher than the one caused by males in the control, it is possible to predict that females feed more than males and, consequently, the first ones were strongly affected by the antifeedant effect of neem oils. The reduction in number of feeding sheaths and in percentage of damaged grains, 
Table 3. Weight of 100 spikelets, number of feeding sheaths per spikelet, percentage of damaged rice grains, and feeding deterrence index for Oebalus poecilus males (M) and females (F), on rice plants treated with two neem oil formulations (Santo Antônio de Goiás, GO, 2002).

\begin{tabular}{|c|c|c|c|c|c|c|c|c|}
\hline \multirow[t]{2}{*}{ Product } & \multicolumn{2}{|c|}{ Spikelets weight $^{1}(\mathrm{~g})$} & \multicolumn{2}{|c|}{ Damaged grains ${ }^{1}(\%)$} & \multicolumn{2}{|c|}{$\begin{array}{c}\text { Feeding sheaths per } \\
\text { spikelet }^{1}\end{array}$} & \multicolumn{2}{|c|}{$\begin{array}{l}\text { Feeding deterrence index } \\
(\mathrm{FDI})^{2}(\%)\end{array}$} \\
\hline & M & $\mathrm{F}$ & $\mathrm{M}$ & $\mathrm{F}$ & M & $\mathrm{F}$ & $\mathrm{M}$ & $\mathrm{F}$ \\
\hline Dalneem & $3.75 \mathrm{a}$ & $3.20 \mathrm{a}$ & $12.59 \mathrm{a}$ & $14.89 \mathrm{a}$ & $1.32 \mathrm{a}$ & $1.38 \mathrm{a}$ & $-28.72 a$ & $-38.85 b$ \\
\hline Nim-I-Go & $3.14 \mathrm{a}$ & $3.15 \mathrm{a}$ & $7.34 \mathrm{a}$ & $16.46 \mathrm{~b}$ & $1.82 \mathrm{a}$ & $1.75 \mathrm{a}$ & $-15.58 \mathrm{a}$ & $-27.91 b$ \\
\hline Control & $1.82 \mathrm{a}$ & $0.95 \mathrm{~b}$ & $22.52 \mathrm{a}$ & $57.99 \mathrm{~b}$ & $2.28 \mathrm{a}$ & $2.93 \mathrm{~b}$ & - & - \\
\hline
\end{tabular}

${ }^{1}$ Means followed by the same letter in lines are not significantly different ( $t$ test; $p<0.05$ ), by variable. ${ }^{2}$ Feeding deterrence index (FDI) was calculated based on number of feeding sheaths per spikelet, using the expression $[(\mathrm{A}-\mathrm{B}) /(\mathrm{A}+\mathrm{B})] \mathrm{x} 100$, where $\mathrm{A}=$ number of feeding sheaths on panicles treated with neem oils and $\mathrm{B}=$ number of feeding sheaths on positive controls (adapted from Fenemore 1980). Index values ranged from +100 for total stimulation, through 0 for no effect, to -100 for total deterrence.

plus the higher spikelet weight observed in treatments with neem, when compared to untreated plants, confirmed that neem oils had antifeedant effect on this insect. Singha et al. (2007) observed mouthpart deformations on another heteroptera, Nezara viridula (Linnaeus) (Hemiptera: Pentatomidae), after topical exposure to neem seed kernel extracts, although this still needs to be tested on O. poecilus. The antifeedant properties of neem oil can also happen due to its triterpenoids compounds, which act on the chemoreceptors of insects (Mordue \& Blackwell 1993). Neem oil triterpenoids like azadirone, nimbin, and salannin, for example, have strong antifeedant activity on insects, although some of these simple compounds can lack toxicity to some pests (Aerts \& Mordue 1997). However, azadiracthtin is an exception among the neem triterpenoids because, additionally to its antifeedant activity, its ingestion leads to deleterious effects on insects (Isman 2006).

Neem oil caused a significant adults mortality rate by ingestion ( $45 \%$ ) only at the $4 \%$ concentration level (Figure 1). Sutherland et al. (2002) also observed that only at higher concentrations neem oil products caused significant mortality rates by contact to $O$. poecilus. These authors evaluated the effect of three neem oil commercial formulations (Neemactin, Agroneem, and Neem-X) and a neem kernel extract, at $0 \%, 12.5 \%, 25 \%, 50 \%$, and $100 \%$ of the recommended rates, and observed mortality levels around $35 \%$ and $40 \%$, similar to the present study. These results indicated that neem oil can cause mortality of adults both by contact or ingestion, although the mortality rates were lower than those observed for other insect orders (Kavallieratos et al. 2007, Venzon et al. 2007).

The lower mortality rate observed in this study is probably because adults are less susceptible to neem oil than nymphs. Several authors observed that neem oil cause high mortality rates in nymphal stages of many insect species (Kumar \& Poehling 2006, Nathan et al. 2006, Sankari \& Narayanasamy 2007), but not always in the adult stage. Ma et al. (2005) did not observe lethal effect of neem oil extracts against adults of Leptocorisa chinensis (Dallas) (Hemiptera: Alydidae), an important rice bug in Asia. This probably occurs because neem acts as a growth regulator on nymphs, preventing their development to the adult stage.

Nathan et al. (2007) observed that in sub-lethal concentrations, neem could cause deformations in the planthopper Nilaparvata lugens (Stål) (Hemiptera: Delphacidae) nymphs. However, high concentrations of neem are indispensable to cause high mortality rates, in accordance with those authors. Kavallieratos et al. (2007) also observed that only at high rates and longer exposure times the neem oil had insecticidal effect against Sitophilus oryzae (Linnaeus) (Coleoptera: Curculionidae) and Tribolium confusum (Jacquelin du. Val) (Coleoptera:

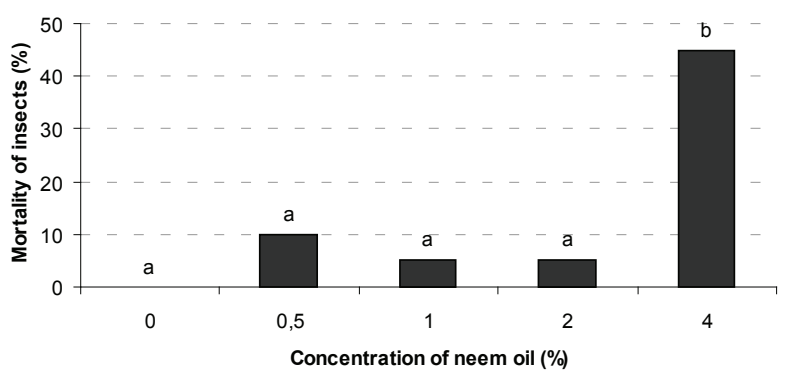

Figure 1. O. poecilus adults mortality rate after treatment of rice panicle with neem oil, at different concentration levels (Santo Antônio de Goiás, GO, 2002). Means followed by the same letters above bars indicate no significant difference ( $\mathrm{t}$ multiple range test; $\mathrm{p}<0.05$ ). 
Tenebrionidae), which is not viable due to cost reasons. In the present study, no phytotoxic effect of neem was observed on rice plants.

Because of the mixture of compounds present in the neem oil, in which azadirachtin is abundant, there is a low probability of the insects being selected for resistance (Mordue \& Nisbet 2000). Therefore, neem oil may be used to protect the crop in critical stages, like the seed-filling stage of rice grains, when this insect can cause severe damage, thus avoiding insect resistance selection. The use of neem oil is considered safe for the environmental and human health and did not cause mortality to natural enemies of rice pests, according to Raguraman \& Rajasekaran (1996) and Dash et al. (2001). However, Price \& Schuster (1991) and Raguraman \& Singh (1999) observed that neem reduces the oviposition in some parasitoid species. Raguraman \& Singh (1999), for example, observed that neem extract applied on Corcyra cephalonica (Lepidoptera: Pyralidae) eggs, at concentration levels between $0.3 \%$ and $5 \%$, caused inhibition effect to the Trichogramma chilonis (Hymenoptera: Trichogrammatidae) oviposition. These results point out that, as any other chemical product with insecticidal properties, neem should be cautiously used, and only when strictly necessary.

Combined with other practices, like avoiding successive rice plantings in nearby areas, keeping the area free of weed species, mainly the host plant of this insect pest, destroying plant remains after harvest and choosing short cycle cultivars, the use of neem oil may be the key to obtain an eco-friendly rice production system.

\section{CONCLUSIONS}

1. The Dalneem and Nim-I-GO neem oils present antifeedant effect on $O$. poecilus adults.

2. The feeding inhibition of Dalneem and Nim-I-GO oils on $O$. poecilus females is higher than on males.

3. Neem oil at $\geq 1 \%$ concentration levels can reduce qualitative and quantitative losses, due to the O. poecilus of lowland rice.

4. Neem oils at $\geq 4 \%$ concentration levels can cause mortality of $O$. poecilus adults.

\section{AKNOWLEDGEMENTS}

We are grateful to Edson H. N. Vieira, Ana Lúcia Delalibera de Faria, and Nand Kumar Fageria, for reviewing the manuscript. To the laboratory team, we thank the supporting and dedication on the development of this study, especially to Edmar C. de Moura, José Francisco de A. e Silva, Genoquinha V. Machado, and Carlos H. R. da Silva.

\section{REFERENCES}

ABUDULAI, M.; SHEPARD, B. M.; MITCHELL, P. L. Antifeedant and toxic effects of a neem (Azadirachta indica A. Juss)-based formulation Neemix (R) against Nezara viridula (L.) (Hemiptera: Pentatomidae). Journal of Entomological Science, Tifton, v. 38, n. 3, p. 398-408, 2003.

AERTS, R. J.; MORDUE, A. J. Feeding deterrence and toxicity of neem triterpenoids. Journal of Chemical Ecology, New York, v. 23, n. 9, p. 2117-2132, 1997.

AHMAD, F.; KHAN, F. R.; KHAN, M. R. Comparative efficacy of some traditional and nontraditional insecticides against sucking insect pests of cotton. Sarhad Journal of Agriculture, Khyber Pukhtunkhwa, v. 11, n. 6, p. 733739, 1995.

BOWLING, C. C. The stylet sheath as an indicator of feeding activity of the rice stink bug. Journal of Economic Entomology, Lanham, v. 72, n. 2, p. 259-260, 1979.

BUNTIN, G. D. et al. Chlorosis, photosynthesis and transpiration of azalea leaves after azalea lace bug (Heteroptera: Tingidae) feeding injury. Journal of Economic Entomology, Lanham, v. 89, n. 4, p. 990-995, 1996.

DASH, A. N.; MUKHERJEE, S. K.; SONTAKKE, B. K. Efficacy of some commercial neem formulations against major pests of rice and their safety to natural enemies. Pest Management and Economic Zoology, Solan, v. 9, n. 1, p. 59-64, 2001.

FENEMORE, P. G. Oviposition of potato tuber moth, Phthorimaea operculella Zell. (Lepidoptera: Gelechiidae): identification of host-plant factors influencing oviposition response. New Zealand Journal of Zoology, Wellington, v. 7, n. 3, p. 435-439, 1980.

FERREIRA, E. Pragas e seu controle. In: VIEIRA, N. R. A.; SANTOS, A. B.; SANT'ANA, E. P. (Eds.). A cultura do arroz no Brasil. Santo Antônio de Goiás: Embrapa Arroz e Feijão, 1999.

HUANG, J.; PRAY, C.; ROZELLE, S. Enhancing the crops to feed the poor. Nature, London, n. 418, p. 678-684, 2002.

ISMAN, M. B. Botanical insecticides, deterrents, and repellents in modern agriculture and an increasingly regulated world. Annual Review of Entomology, Stanford, v. 51, n. 1, p. 45-66, 2006.

KAVALLIERATOS, N. G. et al. Effect of two azadirachtin formulations against adults of Sitophilus oryzae and Tribolium confusum on different grain commodities. Journal of Food Protection, Des Moines, v. 70, n. 7, p. 1627-1632, 2007. 
KENNARD, C. P. Effect of the paddy bug, Oebalus poecilus, on rice yield and quality in British Guyana. FAO Plant Protection Bulletin, Lanham, v. 14, n. 3, p. 54-57, 1966.

KUMAR, P.; POEHLING, H. M. Persistence of soil and foliar azadirachtin treatments to control sweetpotato whitefly Bemisia tabaci Gennadius (Homoptera: Aleyrodidae) on tomatoes under controlled (laboratory) and field (netted greenhouse) conditions in the humid tropics. Journal of Pest Science, Berlin, v. 79, n. 2, p. 189199, 2006.

LACERDA, M. C. et al. Development and reproduction of Podisus distinctus (Heteroptera: Pentatomidae) fed on larva of Bombyx mori (Lepidoptera: Bombycidae). Brazilian Journal of Biology, São Carlos, v. 64, n. 2, p. 237-242, 2004.

MA, D. L. et al. Ovicidal and ovipositional effects of neem (Azadirachta indica A. Juss.) extracts on rice bug, Leptocorisa chinensis (Dallas). International Journal of Pest Management, London, v. 51, n. 4, p. 265-271, 2005.

MACILWAIN, C. Access issues may determine wheter agri-biotech will help the world's poor. Nature, London, n. 402, p. 341-345, 1999.

MARTINEZ, S. S. Composição do nim. In: MARTINEZ, S. S. (Ed.). O nim Azadirachta indica: natureza, usos múltiplos, produção. Londrina: Instituto Agronômico do Paraná, 2002. p. 23-30.

MITCHEL, P. L. et al. Behavioral and developmental effects of neem extracts on Clavigralla scutelaris (Hemiptera: Heteroptera: Coreidae) and its egg parasitoid, Gryon fulviventre (Hymenoptera: Scelionidae). Journal of Economic Entomology, Lanham, v. 97, n. 3, p. 916923, 2004.

MORDUE, A. J.; BLACKWELL, A. Azadirachtin: an update. Journal of Insect Physiology, Oxford, v. 39, n. 11, p. 903-924, 1993.

MORDUE, A. J.; NISBET, A. J. Azadirachtin from the neem tree Azadirachta indica: its actions against insects. Anais da Sociedade Entomológica do Brasil, Jaboticabal, v. 29, n. 4, p. 615-632, 2000.

NATHAN, S. S. et al. The toxic effects of neem extract and azadirachtin on the brown planthopper, Nilaparvata lugens (Stal) (BHP) (Homoptera: Delphacidae). Chemosphere, Oxford, v. 67, n. 1, p. 80-88, 2007.

NATHAN, S. S.; KALAIVANI, K.; MURUGAN, K. Effect of biopesticides on the lactate dehydrogenase (LDH) of the rice leaffolder, Cnaphalocrocis medinalis (Guenée) (Insecta: Lepidoptera: Pyralidae). Ecotoxicology and Environmental Safety, New York, v. 65, n. 1, p. 102-107, 2006.

PRICE, J. F.; SCHUSTER, D. J. Effects of natural and synthetic insecticides on sweetpotato whitefly Bemisia tabaci (Homoptera: Aleyrodidae) and its hymenopterous parasitoids. Florida Entomologist, Gainesville, v. 74, n. 1, p. 60-68, 1991.
QUINTELA, E. D.; PINHEIRO, P. V. Redução da oviposição de Bemisia tabaci (Genn.) biótipo B (Hemiptera: Aleyrodidae) em folhas de feijoeiro tratadas com extratos botânicos. Bioassay, Piracicaba, v. 4, n. 8, p. 1-10, 2009.

RAGURAMAN, S.; RAJASEKARAN, B. Effect of neem products on insect pests of rice and the predatory spider. Madras Agricultural Journal, Coimbatore, v. 83, n. 8, p. 510-515, 1996.

RAGURAMAN, S.; SINGH, R. P. Biological effects of neem (Azadirachta indica) seed oil on an egg parasitoid, Trichogramma chilonis. Journal of Economic Entomology, Lanham, v. 92, n. 6, p. 1274-1280, 1999.

RAJAPPAN, K. et al. Effect of botanicals on the population dynamics of Nephotettix virescens, rice tungro disease incidence and yield of rice. Phytoparasitica, Bet Dagan, v. 28, n. 2, p. 1-5, 2000.

RASHID, T.; JOHNSON, D. T.; BERNHARDT, J. L. Feeding preference, fecundity and egg hatch of rice stink bug on artificial diet, rice and alternate host grasses. Southwestern Entomologist, Weslaco, v. 30, n. 4, p. 257$262,2005$.

ROEL, R. A. Utilização de plantas com propriedades inseticidas: uma contribuição para o desenvolvimento rural sustentável. Revista Internacional de Desenvolvimento Local, Campo Grande, v. 1, n. 2, p. 43-50, 2001.

SANKARI, S. A.; NARAYANASAMY, P. Bio-efficacy of flyash-based herbal pesticides against pests of rice and vegetables. Current Science, Bangalore, v. 92, n. 6, p. 811-816, 2007.

SAS INSTITUTE. SAS/STAT Software: changes and enhancements through release 9.1. Cary: SAS Institute Incorporation, 2002.

SILVA, D. R.; FERREIRA, E.; VIEIRA, N. R. A. Avaliação de perdas causadas por Oebalus spp. (Hemiptera: Pentatomidae) em arroz de terras altas. Pesquisa Agropecuária Tropical, Goiânia, v. 32, n. 1, p. 39-45, 2002.

SINGHA, A.; THAREJA, V.; SINGH, A. K. Application of neem seed kernel extracts result in mouthpart deformities and subsequent mortality in Nezara viridula (L.) (Hem: Pentatomidae). Journal of Applied Entomology, Berlin, v. 131, n. 3, p. 197-201, 2007.

SUTHERLAND, J. P.; BAHARALLY, V. The influence of weather on the population dynamics of rice stink bug and the implications for integrated pest management. International Journal of Pest Management, London, v. 49, n. 4, p. 335-342, 2003.

SUTHERLAND, J. P.; BAHARALLY, V.; PERMAUL, D. Use of botanical insecticide neem to control the small rice stinkbug Oebalus poecilus (Dallas, 1851) (Hemiptera: Pentatomidae) in Guyana. Entomotropica, Maracay, v. 17, n. 1, p. 97-101, 2002.

VENZON, M. et al. Toxicidade letal e subletal do nim sobre o pulgão-verde e seu predador Eriopsis connexa. Pesquisa Agropecuária Brasileira, Brasília, DF, v. 42, n. 5, p. 627-631, 2007. 